\title{
Mandatory Adoption Of IFRS And Earnings Transparency In Korea
}

Hoyoung Shin, Hanyang University, South Korea

Hyunmin Oh, Hanyang University, South Korea

\begin{abstract}
We investigate the relation between mandatory adoption of IFRS (International Financial Reporting Standards) and earnings transparency in Korea. We define transparency of earnings as how well it explains a firm value. Financial reporting mitigates information risks of the firm by lessening information asymmetry between insiders and outsiders of a firm. If accounting information produced after adopting IFRS better explains a firm value, then, it will reduce information asymmetry and information risks of the firm, resulting in enhancement of earnings transparency. We measure earnings transparency based on Barth, Konchitchki, and Landsman et al. (2013) and Cheng and Subramanyam (2008).

The sample is 2,276 which are listed on Korea stock exchange over 2008-2014. The empirical result shows adopting IFRS is significantly positive with earnings transparency, which means it mitigates information asymmetry, enhancing earnings transparency in Korea.
\end{abstract}

Our study is distinguished from prior studies because we empirically examine influence of adopting IFRS on earnings transparency of Korea. Our result implies adopting IFRS contributes to higher earnings transparency which helps market participants make decisions.

Keywords: Earnings Transparency; IFRS; Information Risk; Information Asymmetry

\section{INTRODUCTION}

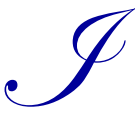
encouraging changes in corporate governance, accounting transparency of firms is still an issue. ${ }^{1}$ Thus, it is yet important to empirically test whether adopting International Financial Reporting Standards (IFRS) enhances earnings transparency in Korea. Korean listed firms must follow IFRS to prepare consolidated financial statements starting from 2011.

Ball and Shivakumar (2005) argue that widespread adoption of IFRS could lead to more accurate, comprehensive, and timely information and greater comparability of financial statements across countries. However, there are doubts about benefits of IFRS adoption. Since IFRS allow many alternatives in preparing and disclosing financial statements and are principle-based, managerial discretion might increase, deteriorating quality of earnings. There are also concerns on extremely high costs for implementations of and compliance with IFRS.

Prior research documents that adoption of IFRS improves the quality of accounting information in Korea (Lee, Jin \& Lee, 2015; Jang, In, Lee, Seo \& Cheung, 2016). ${ }^{2}$ Lee et al. (2015) find that explanatory powers of earnings and equity

\footnotetext{
${ }^{1}$ The Financial Services Commission found accounting fraud and ordered Daewoo Shipbuilding \& Marine Engineering Co. to rewrite its incorrect financial statements from 2008 to the first quarter of 2016. An accounting firm was suspended conducting new audits for one year as punishment. In 2016, International Institute for Management Development (IMD) of Switzerland ranked Korea as the lowest among 61 countries surveyed in the accounting transparency category.

${ }^{2}$ Financial reporting quality is one of the key determinants of analyst forecast accuracy (Bradshaw, Richardsom \& Sloan, 2001; Jeong \& Lim, 2005; Cho \& Jo, 2009; Kang, Lee \& Lee, 2013). 
book value have increased from pre-IFRS periods to post-IFRS periods and value relevance improved after IFRS adoption. However, Choi (2013) and Choi, Park \& Choi (2013) fail to find any significant differences in value relevance after IFRS adoption. The limitation of these studies is that they use the samples obtained from only one or two years after the adoption of IFRS. We use longer periods to better observe potential changes in earnings transparency from pre-IFRS to post-IFRS periods.

If accounting information after adopting IFRS better explains a firm value, it will increase information usefulness and contribute to an efficient allocation of economic resources. We use earnings transparency as a surrogate for accounting transparency and test whether mandatorily adopting IFRS improves earnings transparency of Korea.

Earnings transparency is measured based on Barth et al. (2013) and Cheng and Subramanyam (2008). We define earnings transparency as how well it explains a firm value. Transparent firms may better describe the economic value of a firm. We develop a measure equal to the explanatory power of the returns-earnings relation in which earnings and change in earnings move contemporaneously with stock returns.

Using a sample of 2,276 from the Korea Stock Exchange during 2008 - 2014, we find adopting IFRS is significantly positive with transparency of earnings. Our results imply adopting IFRS contributes to higher level of earnings transparency and helps market participants make decisions.

Our paper directly tests the relation between the full adoption of IFRS and earnings transparency of firms in Korea by using longer sample periods to enhance our understanding of the economic consequences of accounting numbers. It complements prior research by examining the impact of mandatory adoption of IFRS on earnings transparency, in particular using earnings transparency measures developed by Barth et al. (2013) and Cheng and Subramanyam (2008). ${ }^{3}$ Another evidence will be accumulated to enhance our understanding of the Korean financial market and reporting system.

After an introduction, 2 reviews prior literature and develops hypothesis. 3 presents research method. 4 reports results. Finally, 5 explains the conclusion.

\section{LITERATURE REVIEW AND HYPOTHESIS DEVELOPMENT}

According to a recent survey, general accounting works of Korean companies increased significantly and accounting personnel reinforced since the adoption of IFRS and discretionary judgement and outside inquiry or consulting for accounting issues increased significantly, reflecting the difficulties faced by firms that were used to rule-based accounting standards rather than principle-based (Han \& Lee, 2017). Accordingly, adoption of IFRS may not enhance comparability across firms or comparability across years within the same firm as expected.

Prior studies report that managerial discretion increased and consequently, earnings quality deteriorated further (Capkun, Jeny, Jeanjean \& Weiss, 2011; Ahmed, Neel \& Wang, 2013). However, Barth, Landsman and Lang (2008) and Yip and Young (2012) report that financial reporting quality and analysts' forecasts have improved after adopting IFRS. Leuz and Verrecchia (2000) document that information asymmetry decreased after the adoption of IFRS. Daske, Hail, Leuz and Verdi (2008) find that the adoption of IFRS reduces the cost of equity as the market liquidity increases. ${ }^{4}$ In Korea, adoption of IFRS improves the quality of accounting information (Jang et al. 2016). However, most of these studies use a short period of time to examine the impact of IFRS on accounting information quality.

There are mixed results about the effect of IFRS adoption on value relevance. The impact of IFRS adoption on value relevance in the United Kingdom and EU is positive (Horton et al. 2010; Barth et al. 2008) while value relevance of both earnings and book value has decreased in Spain and Italy (Lee et al. 2015). Arising in the transition from previous accounting standards to IFRS, the adjustments to net income provide incremental value-relevance, but the adjustments to net assets do not have any incremental effect (Kim, Choi, Kim \& Kim, 2014) or actually decrease value-relevance

\footnotetext{
${ }^{3}$ Cheng and Subramanyam (2008) uses the methodology developed by Gu (2002).

${ }^{4}$ Barth et al. (2013) provide evidence that transparent firms enjoy lowered financing costs. Shin and Park (2014) show that financial statement comparability reduces differences of opinion among investors in Korea, which helps reduce 'Korea Discount' phenomenon.
} 
(Choi et al. 2013; Kim \& Kim, 2015). The optimistic bias in analyst recommendations has increased after the adoption of IFRS (Yoon \& Mo, 2016). Since results of prior research are not conclusive, we need to continue to test the effect of adoption of IFRS on accounting information quality to improve our understanding of accounting numbers. Using earnings transparency as a surrogate for accounting information quality as well as accounting transparency, we expect that adopting IFRS reduce information asymmetry and be positively associated with earnings transparency in Korea. Thus, following hypothesis is proposed:

Hypothesis: Mandatorily adopting IFRS enhances earnings transparency in Korea.

\section{RESEARCH METHODOLOGY}

\subsection{Model Specification}

To test the hypothesis, we use the following model (1)

$$
\begin{aligned}
& \text { TRANS }_{i t}=\beta_{0}+\beta_{1} I F R S_{i t}+\beta_{2} A Q_{i t}+\beta_{3} S I Z E_{i t}+\beta_{4} L E V_{i t}+\beta_{5} L O S S D U M_{i t}+\beta_{6} A G E_{i t}+\beta_{7} G R W_{i t}+ \\
& \beta_{8} \text { FOR }_{i t}+\beta_{9} O W N_{i t}+\beta_{10} B I G 4_{i t}+\sum Y D+\sum I D+\varepsilon_{i t}
\end{aligned}
$$

Here, $\mathrm{i}$ and $\mathrm{t}$ indicate firm $\mathrm{i}$ and year $\mathrm{t}$. where,

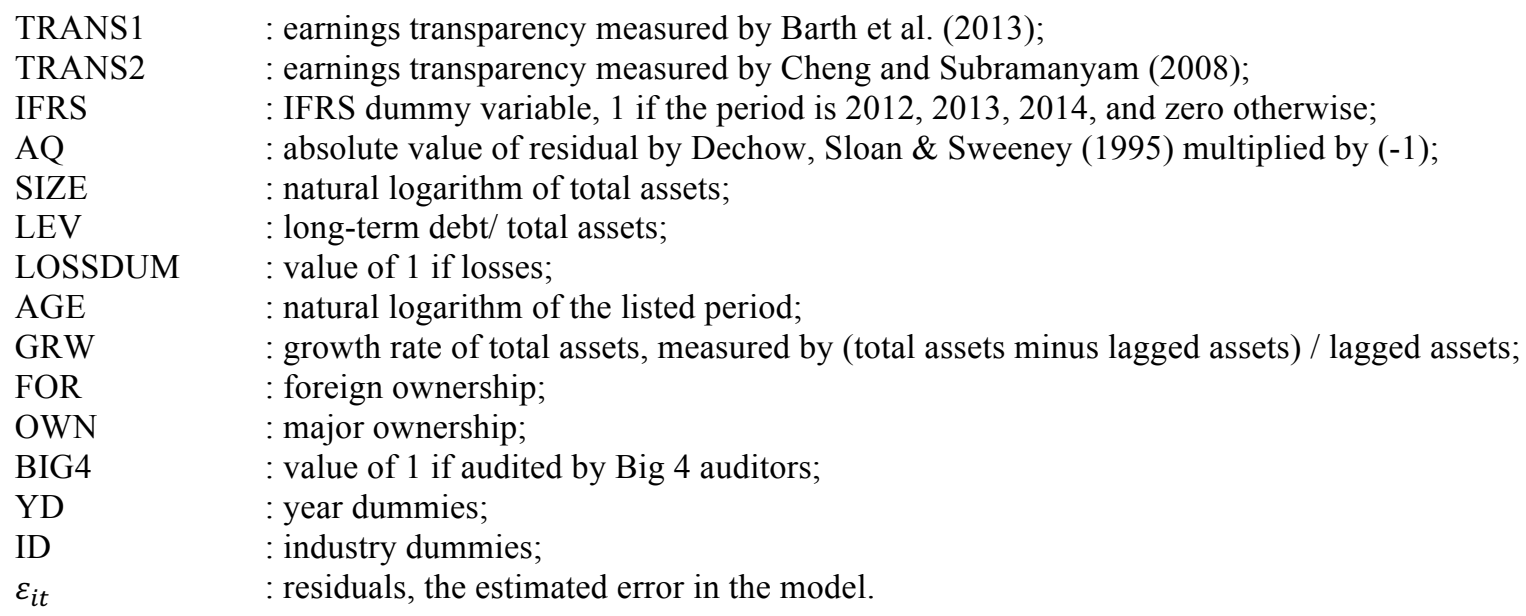

The dependent variable, TRANS, is the earnings transparency, which is based on measures of Barth et al. (2013) and Cheng and Subramanyam (2008). The independent variable is IFRS, one if the period is 2012, 2013, 2014, and zero otherwise. If IFRS improves earnings transparency, we expect a coefficient on IFRS to be $\beta_{1}>0$.

Based on Barth et al. (2013), we measure our earnings transparency as follows: ${ }^{5}$

$$
\operatorname{TRANS}_{i, t}=\operatorname{TRANSI}_{j, t}+\operatorname{TRANSIN} \mathrm{N}_{p, t}
$$

To calculate $T R A N S I_{j, t}$, we estimate Eq. (3):

$$
R E T_{i, j, t}=\alpha_{0}^{I}+\alpha_{1}^{I} E_{i, j, t} / P_{i, j, t-1}+\alpha_{2}^{I} \Delta E_{i, j, t} / P_{i, j, t-1}+\varepsilon_{i, j, t}
$$

To calculate $\operatorname{TRANSIN}_{p, t}$, we estimate Eq. (4):

\footnotetext{
${ }^{5}$ In this study, we use variables of Barth et al. (2013). However, instead of measuring earnings transparency by using 108 regression analyses as in Barth et al. (2013), we estimate it by using an industry-year cross-sectional method for the total sample.
} 


$$
R E T_{i, p, t}=\alpha_{0}^{I N}+\alpha_{1}^{I N} E_{i, p, t} / P_{i, p, t-1}+\alpha_{2}^{I N} \Delta E_{i, p, t} / P_{i, p, t-1}+\varepsilon_{i, p, t}
$$

RET : annual returns from beginning three months after fiscal year end;

E : earnings;

$\mathrm{P} \quad$ : the previous year-end price;

$\triangle \mathrm{E} \quad$ : change in earnings.

Eq. (2) expresses TRANS1i,t earnings transparency measure, as sum of two measures, TRANSIj,t and TRANSINp,t. TRANSIj,t is the sum of $R^{2} \mathrm{~s}$ from regressions on returns and earnings estimated by industry in equation (3). TRANSINp,t is the sum of $R^{2} s$ from regressions estimated by portfolio in equation (4). In estimating TRANSINp,t observations from each industry-year regression in equation (3) are placed into one of four portfolios based on residuals from annual regressions for that industry. The portfolio regression reflects differences in returns-earnings relations not measured fully by industry estimation. Portfolios are industry neutral because of same industry composition.

EPSt/Pt-1 and $\triangle \mathrm{Et} / \mathrm{Pt}-1$ are deflated by beginning of year price. Earnings transparency is measured by the explanatory power of returns-earnings relation. More transparent firms are those whose earnings better explain the economic value of a firm. Higher explanatory power in returns-earnings regressions indicates greater earnings transparency.

Based on Cheng and Subramanyam (2008), we measure our earnings transparency as follows:

$$
\begin{aligned}
& \operatorname{ARET}_{i t}=\beta_{0}+\beta_{1} N I_{i t}+\beta_{2} \text { LOSS }_{i t}+\beta_{3} N I_{i t} \times \operatorname{LOSS}_{i t}+\beta_{4} \Delta N I_{i t}+\varepsilon_{i t} \\
& \operatorname{TRANS}_{i t}=\left[\operatorname{ARET}_{i t}-\left(\hat{\beta}_{0}+\hat{\beta}_{1} N I_{i t}+\hat{\beta}_{2} \text { LOSS }_{i t}+\hat{\beta}_{3} N I_{i t} \times \operatorname{LOSS}_{i t}+\hat{\beta}_{4} \Delta N I_{i t}\right)\right]^{2}
\end{aligned}
$$

\footnotetext{
$\mathrm{ARET}_{\mathrm{it}} \quad:$ market adjusted return over the fiscal year;

LOSS $_{\text {it }} \quad:$ one if negative income, zero otherwise;

$\mathrm{NI}_{\text {it }} \quad:$ net income/ beginning market value of equity;

$\Delta \mathrm{NI}_{\mathrm{it}} \quad$ : change in net income/ beginning market value of equity
}

The stock returns are measured by applying the regression coefficients measured by the industry-year regressions in equation (5). The earnings transparency is measured by the difference between stock returns and market adjusted returns. To measure the magnitude of this difference, we square the values obtained by subtracting the stock returns from the market adjusted returns as shown in equation (6). In order to have a property whose value increases as the earnings transparency increases, we multiply the squared residuals in equation (6) by negative one (-1).

Based on previous research, we use control variables. To control information environment, we use natural log of total assets (SIZE) (Lang \& Lundholm, 1996). Total assets minus lagged assets deflated by lagged assets, GRW is included to control a firm's growth. To control information uncertainty, solvency, and negative income, auditor quality, and earnings management, we include AGE, LEV, LOSS, FOR, OWN, BIG4 and AQ. If the debt ratio (LEV) is high, firms will be reluctant to disclose information. As the debt ratio affects the information asymmetry, it is added as a control variable (Cho \& Jo, 2010; Oh \& Shin, 2016). Debt ratio predict a positive relationship with information. Firms with a negative income (LOSSDUM) and a high growth rate (GRW) have large uncertainties in the market, so they predict a negative relationship with earnings transparency. Firms with long AGE predict a positive relationship with earnings transparency because the information environment is abundant in the market. Accruals quality (AQ) predicts a negative relationship with earnings transparency because it is expected that earnings transparency lowers earnings management.

\subsection{Sample Selection}

In Table 1, we first eliminate the quoted non-financial December firms. Those whose data cannot be collected from the Kis-Value and FN-Guide are deleted. Final sample for the model is 2,276 firm-year observations from the Korea Stock Exchange from 2008 till 2014. To avoid the dilution of the regression result, we delete those which mandatorily 
adopted IFRS in 2011 and those which voluntarily adopted K-IFRS before 2011. We winsorize at the 1st and 99th percentiles.

Table 1. Sample

\begin{tabular}{l|c}
\hline \multicolumn{1}{c}{ Criteria } & Observations \\
\hline Quoted non-financial December 31 firms for years 2008-2014 & 4,306 \\
\hline (less) Those mandatorily adopt IFRS in 2011 & $(623)$ \\
\hline (less) Financial and stock data cannot collect from Kis-Value and FN-Guide & $(1,252)$ \\
\hline (less) Firms voluntarily adopt IFRS before 2011 ${ }^{6}$ & $(155)$ \\
\hline Total & 2,276 \\
\hline
\end{tabular}

Table 2. Distribution

\begin{tabular}{r|c|c}
\hline Panel A: Distribution by year & & Number \\
\hline Year & 306 & 13.44 \\
\hline 2008 & 316 & 13.88 \\
\hline 2009 & 330 & 14.50 \\
\hline 2010 & 430 & 18.89 \\
\hline 2012 & 443 & 19.46 \\
\hline 2013 & 451 & 19.82 \\
\hline 2014 & 2,276 & 100 \\
\hline
\end{tabular}

Panel B: Distribution by industry

\begin{tabular}{l|c|c} 
& \multicolumn{1}{c}{ Industry } & Number \\
\hline Food \& beverages & 156 & 6.85 \\
\hline Textile \& leather products & 125 & 5.49 \\
\hline Woods \& pulp products & 66 & 2.90 \\
\hline Chemicals \&chemical products & 234 & 10.28 \\
\hline Medical \& manufacturing & 76 & 3.34 \\
\hline Metallic & 169 & 7.43 \\
\hline Pc \& medical & 150 & 6.59 \\
\hline Machine \& electronic & 173 & 7.60 \\
\hline Motor vehicles \& other transport equipment products & 201 & 8.83 \\
\hline Construction & 132 & 5.80 \\
\hline Wholesale \& retail trade & 217 & 9.53 \\
\hline Transportation & 76 & 3.34 \\
\hline Publishing \& broadcating & 54 & 2.37 \\
\hline Professional Services & 312 & 13.71 \\
\hline Other & 135 & 5.93 \\
\hline Total & 2,276 & 100.00 \\
\hline
\end{tabular}

\section{EMPIRICAL RESULTS}

\subsection{Descriptive Statistics}

In PANEL A of Table 3, mean (median) of TRANS1 is 0.380 (0.383), indicating an average 38\% of earnings transparency of companies. The mean (median) of TRANS2 is $-0.253(-0.044)$. The mean (median) of IFRS is 0.582 (1.0), implying that $58.2 \%$ adopt IFRS mandatorily after the IFRS adoption year of 2011. Most other control variables are normally distributed. PANEL B of Table 3 presents the annual change values of TRANS1, TRANSI, TRANSIN, and TRANS2.

${ }^{6}$ In this study, the KOSPI listed non-financial December 31 firms were selected as a sample. Among them, 7 firms were introduced early in 2009 and 24 firms were introduced early in 2010. A total of 31 firms were introduced early. Of the 186 firm-year observations of six years, 31 firms with no financial data were excluded, and the remaining 155 samples were additionally removed. 
Table 3. Descriptive Statistics ( $\mathrm{N}=2,276)$

\begin{tabular}{|c|c|c|c|c|c|c|c|}
\hline \multicolumn{8}{|l|}{ Panel A. } \\
\hline Variable & Mean & Std. Dev. & Min & $25 \%$ & Median & $75 \%$ & Max \\
\hline TRANS1 & 0.380 & 0.213 & -0.026 & 0.228 & 0.383 & 0.521 & 0.883 \\
\hline TRANS2 & -0.253 & 0.599 & -2.412 & -0.146 & -0.044 & -0.009 & 0.000 \\
\hline IFRS & 0.582 & 0.493 & 0.000 & 0.000 & 1.000 & 1.000 & 1.000 \\
\hline$A Q$ & -0.051 & 0.056 & -0.305 & -0.068 & -0.032 & -0.013 & 0.000 \\
\hline SIZE & 27.266 & 1.587 & 24.334 & 26.123 & 26.996 & 28.217 & 31.767 \\
\hline$L E V$ & 0.507 & 0.194 & 0.113 & 0.363 & 0.525 & 0.644 & 0.965 \\
\hline LOSSDUM & 0.239 & 0.427 & 0.000 & 0.000 & 0.000 & 0.000 & 1.000 \\
\hline$A G E$ & 2.810 & 0.861 & 0.000 & 2.398 & 3.045 & 3.526 & 4.078 \\
\hline$G R W$ & 0.137 & 0.748 & -0.966 & -0.020 & 0.048 & 0.150 & 8.977 \\
\hline FOR & 0.109 & 0.140 & 0.000 & 0.010 & 0.050 & 0.156 & 0.897 \\
\hline$O W N$ & 0.431 & 0.166 & 0.020 & 0.313 & 0.427 & 0.539 & 0.900 \\
\hline$B I G 4$ & 0.690 & 0.462 & 0.000 & 0.000 & 1.000 & 1.000 & 1.000 \\
\hline
\end{tabular}

Panel B.

\begin{tabular}{|c|c|c|c|c|c|c|c|c|c|}
\hline Year & n & Variable & Mean & Std. Dev. & Min & $25 \%$ & Median & $75 \%$ & Max \\
\hline \multirow{4}{*}{2008} & \multirow{4}{*}{306} & $\triangle T R A N S 1$ & 0.100 & 0.194 & -0.470 & -0.040 & 0.084 & 0.213 & 0.648 \\
\hline & & $\triangle T R A N S I$ & 0.056 & 0.207 & -0.506 & -0.068 & 0.051 & 0.198 & 0.696 \\
\hline & & $\triangle T R A N S I N$ & 0.153 & 0.110 & -0.314 & 0.085 & 0.156 & 0.229 & 0.367 \\
\hline & & $\triangle T R A N S 2$ & 0.291 & 0.746 & -2.396 & -0.004 & 0.039 & 0.173 & 2.412 \\
\hline \multirow{4}{*}{2009} & \multirow{4}{*}{316} & $\triangle T R A N S 1$ & 0.122 & 0.025 & -0.805 & -0.036 & 0.133 & 0.309 & 0.648 \\
\hline & & $\triangle T R A N S I$ & 0.094 & 0.261 & -0.769 & -0.116 & 0.194 & 0.285 & 0.613 \\
\hline & & $\triangle T R A N S I N$ & 0.090 & 0.163 & -0.277 & -0.046 & 0.109 & 0.172 & 0.498 \\
\hline & & $\triangle T R A N S 2$ & 0.007 & 0.660 & -2.936 & -0.133 & -0.027 & 0.014 & 2.411 \\
\hline \multirow{4}{*}{2010} & \multirow{4}{*}{330} & $\triangle T R A N S 1$ & -0.051 & 0.270 & -0.608 & -0.264 & -0.034 & 0.102 & 0.648 \\
\hline & & $\triangle T R A N S I$ & -0.059 & 0.227 & -0.500 & -0.207 & 0.060 & 0.127 & 0.417 \\
\hline & & $\triangle T R A N S I N$ & -0.008 & 0.153 & -0.278 & -0.139 & -0.035 & 0.109 & 0.359 \\
\hline & & $\Delta T R A N S 2$ & 0.088 & 0.621 & -2.887 & -0.053 & 0.006 & 0.097 & 2.412 \\
\hline \multirow{4}{*}{2012} & \multirow{4}{*}{430} & $\triangle T R A N S 1$ & 0.233 & 0.204 & -0.543 & 0.116 & 0.268 & 0.361 & 0.648 \\
\hline & & $\triangle T R A N S I$ & 0.027 & 0.183 & -0.387 & -0.090 & 0.017 & 0.140 & 0.405 \\
\hline & & $\triangle T R A N S I N$ & 0.051 & 0.151 & -0.361 & -0.064 & 0.052 & 0.137 & 0.443 \\
\hline & & $\triangle T R A N S 2$ & 0.094 & 0.670 & -3.678 & -0.056 & 0.004 & 0.097 & 2.410 \\
\hline \multirow{4}{*}{2013} & \multirow{4}{*}{443} & $\triangle T R A N S 1$ & -0.050 & 0.228 & -0.619 & -0.223 & -0.052 & 0.093 & 0.648 \\
\hline & & $\triangle T R A N S I$ & -0.047 & 0.179 & -0.335 & -0.234 & 0.002 & 0.072 & 0.294 \\
\hline & & $\triangle T R A N S I N$ & -0.003 & 0.145 & -0.259 & -0.088 & 0.019 & 0.102 & 0.334 \\
\hline & & $\triangle T R A N S 2$ & 0.093 & 0.598 & -3.893 & -0.042 & 0.003 & 0.089 & 2.412 \\
\hline \multirow{4}{*}{2014} & \multirow{4}{*}{451} & $\triangle T R A N S 1$ & -0.240 & 0.226 & -0.835 & -0.411 & -0.257 & -0.065 & 0.351 \\
\hline & & $\triangle T R A N S I$ & -0.044 & 0.200 & -0.508 & -0.178 & -0.001 & 0.071 & 0.374 \\
\hline & & $\triangle T R A N S I N$ & -0.217 & 0.108 & -0.389 & -0.320 & -0.218 & -0.119 & 0.045 \\
\hline & & $\triangle T R A N S 2$ & -0.057 & 0.664 & -3.716 & -0.125 & -0.016 & 0.043 & 2.412 \\
\hline
\end{tabular}

Variable Definitions

TRANS1 : earnings transparency measured by Barth et al. (2013);

TRANS2 : : earnings transparency measured by Cheng and Subramanyam (2008);

IFRS $\quad: 1$ if the period is 2012, 2013, 2014, and zero otherwise;

AQ : absolute value of residual by Dechow et al. (1995) multiplied by (-1);

SIZE : natural logarithm of total assets;

LEV : long-term debt/ total assets;

LOSSDUM : value of 1 if losses;

AGE : natural logarithm of the listed period;

GRW : growth rate of total assets, measured by (total assets minus lagged assets) / lagged assets;

FOR : foreign ownership;

OWN : major ownership; 


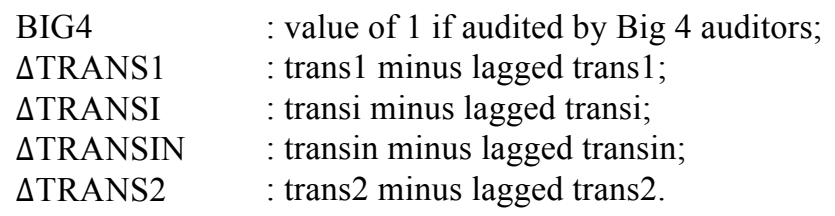

\subsection{Correlation}

In Table 4, TRANS2 only positively correlates with IFRS adoption, which implies adopting IFRS enhances earnings transparency. Regarding control variables, TRANS1 and TRANS2 are positively correlated with AQ, SIZE, and AGE as expected. However, correlation test does not consider control variables. Thus, we neeed to perform the regression analysis.

Table 4. Pearson Correlations $(\mathrm{N}=2,276)$

\begin{tabular}{|c|c|c|c|c|c|c|}
\hline & (1) & (2) & (3) & (4) & (5) & (6) \\
\hline (1)TRANS1 & 1 & $0.481^{\text {*** }}$ & -0.023 & $0.067^{* * *}$ & $0.061^{* * *}$ & $0.051^{* *}$ \\
\hline (2)TRANS2 & & 1 & $0.040^{*}$ & $0.119^{* * *}$ & $0.086^{* * *}$ & 0.016 \\
\hline (3)IFRS & & & 1 & $0.088^{* * *}$ & $-0.038^{*}$ & $-0.067^{* * *}$ \\
\hline (4) $A Q$ & & & & 1 & $0.166^{* * *}$ & $-0.062^{* * *}$ \\
\hline (5) SIZE & & & & & 1 & $0.303^{* * *}$ \\
\hline (6) $L E V$ & & & & & & 1 \\
\hline & (7) & (8) & (9) & (10) & (11) & (12) \\
\hline (1)TRANS1 & 0.018 & $0.188^{* * *}$ & $-0.097^{* * *}$ & 0.020 & -0.033 & 0.001 \\
\hline (2)TRANS2 & 0.018 & $0.378^{* * *}$ & $-0.163^{* * *}$ & $0.061^{* * *}$ & -0.033 & $0.047^{* *}$ \\
\hline (3)IFRS & $0.119^{* * *}$ & 0.033 & $-0.076^{* * *}$ & -0.018 & -0.002 & -0.027 \\
\hline (4) $A Q$ & $-0.123^{* * *}$ & $0.072^{* * *}$ & -0.017 & $0.084^{* * *}$ & $0.09^{* * * *} 1$ & $0.099^{* * *}$ \\
\hline (5) SIZE & $-0.125^{* * *}$ & $0.055^{* * *}$ & $0.139^{* * *}$ & $0.442^{* * *}$ & $-0.050^{* * *}$ & $0.451^{* * *}$ \\
\hline (6) $L E V$ & $0.312^{* * *}$ & 0.033 & $0.047^{* * *}$ & $-0.129^{* * *}$ & $-0.108^{* * *}$ & $0.056^{* * *}$ \\
\hline (7) LOSSDUM & 1 & $0.099^{* * *}$ & $-0.071^{* * *}$ & $-0.155^{* * *}$ & $-0.101^{* * *}$ & $-0.116^{* * *}$ \\
\hline (8) $A G E$ & & 1 & $-0.167^{* * *}$ & -0.034 & $-0.135^{* * *}$ & $-0.058^{* * *}$ \\
\hline (9) $G R W$ & & & 1 & $0.050^{* *}$ & $0.041^{*}$ & $0.068^{* * *}$ \\
\hline (10)FOR & & & & 1 & $-0.184^{* * *}$ & $0.256^{* * *}$ \\
\hline (11) $O W N$ & & & & & 1 & $0.060^{* * *}$ \\
\hline (12)BIG4 & & & & & & 1 \\
\hline
\end{tabular}

1) See Table 3 for variable definitions.

2) $* * *, * * *$ represent $1 \%, 5 \%, 10 \%$ significance level respectively.

\subsection{Results}

In Table 5, coefficients of IFRS are 0.124 for TRANS1 and 0.107 for TRANS2, which are significantly positive as expected, thus supporting our hypothesis that the adoption of IFRS enhances earnings transparency in Korea. The variance inflation factor (VIF) of an independent variable is 3.139 less than 10, which means there is not a serious multicollinearity problem.

Our result implies that adopting IFRS contributes to higher level of earnings transparency in helping market participants make decisions, playing an important role in reducing information asymmetry.

AQ and AGE are significant at 5\% and 1\% respectively as expected. The coefficient of GRW is significantly negative at $1 \%$ as expected. $R^{2}$ ranges approximately from $18 \%$ to $30 \%$. The $\mathrm{F}$ statistic is significant, suggesting that our use of the regression model is appropriate. 
Table 5. Adoption of IFRS and earnings transparency $(\mathrm{H})$

\begin{tabular}{|c|c|c|c|c|c|}
\hline \multicolumn{6}{|c|}{$\begin{array}{l}\text { TRANS }_{i t}=\beta_{0}+\beta_{1} I F R S_{i t}+\beta_{2} A Q_{i t}+\beta_{3} S_{I Z E_{i t}}+\beta_{4} L E V_{i t}+\beta_{5} L_{O S S D U M}+\beta_{6} A G E_{i t}+\beta_{7} G R W_{i t}+\beta_{8} F O R_{i t} \\
+\beta_{9} O W N_{i t}+\beta_{10} B I G 4_{i t}+\sum Y D+\sum I D+\varepsilon_{i t}\end{array}$} \\
\hline \multirow{2}{*}{ Variables } & \multirow{2}{*}{ Exp. Sign } & \multicolumn{2}{|c|}{ Dependent Variable TRANS1 } & \multicolumn{2}{|c|}{ Dependent Variable $T R A N S 2$} \\
\hline & & Coefficient & t-value & Coefficient & t-value \\
\hline INTERCEPT & & 0.051 & 0.600 & -1.439 & $-5.490^{* * *}$ \\
\hline$I F R S$ & $(+)$ & 0.124 & $9.280^{* * *}$ & 0.107 & $2.620^{* * *}$ \\
\hline$A Q$ & $(+)$ & 0.139 & $1.970^{* *}$ & 0.847 & $3.940^{* * *}$ \\
\hline SIZE & $(+)$ & 0.005 & 1.360 & 0.013 & 1.280 \\
\hline$L E V$ & $(-)$ & 0.029 & 1.220 & 0.048 & 0.650 \\
\hline LOSSDUM & $(-)$ & 0.004 & 0.380 & -0.014 & -0.460 \\
\hline$A G E$ & $(+)$ & 0.041 & $8.840^{* * *}$ & 0.254 & $18.050^{* * *}$ \\
\hline$G R W$ & $(-)$ & -0.024 & $-4.730^{* * *}$ & -0.088 & $-5.600^{* * *}$ \\
\hline FOR & $(+)$ & 0.025 & 0.750 & 0.202 & $2.020^{* *}$ \\
\hline$O W N$ & $(+)$ & 0.001 & 0.020 & 0.123 & 1.640 \\
\hline$B I G 4$ & $(+)$ & 0.001 & 0.020 & 0.060 & $2.100^{* *}$ \\
\hline$Y D$ & & YES & YES & YES & YES \\
\hline$I D$ & & YES & YES & YES & YES \\
\hline$F-V A L U E$ & & \multicolumn{2}{|c|}{$35.77^{* * *}$} & \multicolumn{2}{|c|}{$18.45^{* * *}$} \\
\hline$A D J R-S Q$ & & \multicolumn{2}{|c|}{$29.97 \%$} & \multicolumn{2}{|c|}{$17.68 \%$} \\
\hline
\end{tabular}

1) See Table 3 for variable definitions.

2) $* * *, * * *$ represent $1 \%, 5 \%, 10 \%$ significance level respectively (two-tailed).

\section{CONCLUSION}

Korea has adopted IFRS to make the firm's information environment to be more transparent. When firms' financial statements, including its earnings, are more transparent, then the uncertainty about value of firm and information asymmetry will decline. We test whether adopting IFRS mandatorily improves earnings transparency for Korean firms. We measure earnings transparency based on Barth, et al. (2013) and Cheng and Subramanyam (2008).

Using a sample of 2,276 from 2008 to 2014, we find that adopting IFRS increases earnings transparency. This implies IFRS mitigates information asymmetry, enhancing earnings transparency.

We show that adopting IFRS and reporting transparent earnings in financial statements are very important in reducing information asymmetry in capital market, which helps market participants make decisions.

Our paper suffers from an endogeneity issue due to omitted market variables such as volatility and abnormal returns. They should be incorporated in future studies because companies may attempt to make the information environment opaque to avoid adverse reaction from the capital market. Operation complexity variables such as foreign sales and the number of segments are also omitted although they are closely related to information uncertainty. Since private firms in Korea are not required to adopt IFRS, use of private firms as control samples in future may help sharpen the research design and interpret the role of IFRS on the observed results.

\section{AUTHOR BIOGRAPHIES}

Hoyoung Shin, Professor, School of Business, Hanyang University. She has been teaching at Hanyang University in South Korea since 1983. Her research focuses on Disclosure, Information Asymmetry, and Corporate Governance. Hoyoung Shin, Office 516, School of Business, Hanyang University, 222 Wangsimni-ro, Seongdong-gu, Seoul 04763, South Korea. E-mail: shinho@hanyang.ac.kr (First author)

Hyunmin Oh, Ph.D candidate, School of Business, Hanyang University. He has been majoring in Accounting to achieve doctoral degree at Hanyang University in South Korea since 2013. He received the Master of Accounting from Hanyang University. He also has been working at J Accounting Corporation since 2012. His research focuses 
on Analysts' Forecasts, Earnings Management, and Corporate Governance. Hyunmin Oh, Susan B/D, 3, Teheran-ro 6-gil, Gangnam-gu, Seoul, 135-934, South Korea. E-mail: gusals@hanyang.ac.kr_(Corresponding author).

\section{REFERENCES}

Ahmed, A. S., Neel, M. \& Wang, D. (2013). Does mandatory adoption of IFRS improve accounting quality? Preliminary evidence. Contemporary Accounting Research 30(4), 1344-1372.

Ball, R. \& Shivakumar, L. (2005). Earnings quality in U.K. private firms. Journal of Accounting and Economics, 39, 83-128.

Barth, M. E., Landsman, W.R. \& Lang, M.H. (2008). International accounting standards and accounting quality. Journal of Accounting Research 46(3), 467-498.

Barth, M., Konchitchki, Y. \& Landsman, W. (2013). Cost of capital and earnings transparency. Journal of Accounting and Economics, 55(2-3), 206-224.

Bradshaw, M., Richardson, S. \& Sloan, R. (2001). Do analysts and auditors use information in accruals? Journal of Accounting Research, 39(1), 45-74.

Capkun, V., Jeny, A. C., Jeanjean, T. J. \& Weiss, L. A. (2011). Setting the bar: Earnings management during a change in accounting standards. Working Paper.

Cheng, M. \& Subramanyam, K. (2008). Analyst following and credit ratings. Contemporary Accounting Research 25(4), 10071044.

Cho, J. S. \& Jo, M. H. (2009). The effect of managerial opportunistic discretion on analysts' earnings forecasts. Korean Journal of Accounting Research, 14(1), 147-173.

Cho, J. S. \& Jo, M. H. (2010). The Effect Of Accrual Volatility On The Firms' Information Asymmetry, Forecast Error, And Cost Of Capital. Korean Accounting Journal, 19(3), 175-199.

Choi, J. H. (2013). The adoption of IFRS and value relevance of accounting information. Korean Accounting Review, 38(1): 391424.

Choi, K., Park, J. I. \& Choi, S. H. (2013). The effect of IFRS adoption on accounting quality and economic consequences: A literature review and suggestions for future research. Korean Accounting Journal, 38(2), 525-591.

Daske, H., Hail, L., Leuz, C. \& Verdi, R. (2008). Mandatory IFRS reporting around the world: Early evidence on the economic consequences. Journal of Accounting Research, 46(5), 1085-1142.

Dechow, P. M., Sloan, R. G. \& Sweeney, A. P. (1995). Detecting Earnings Management. The Accounting Review 70, $193-225$.

$\mathrm{Gu}$. (2002). Cross-sample Incomparability of R2s and additional evidence on value relevance changes over time. Working paper, Carnegie Mellon University.

Han, B. H. \& Lee, J. (2017). The effect of IFRS adoption on enhancement of financial information usefulness and capital globalization: Based on the recognition of capital globalization practitioners. Korean Accounting Journal, 26(1), 129163.

Horton, J. \& Serafeim, G. (2010). Market reaction to and valuation of IFRS reconciliation adjustments: First evidence from the UK. Review of Accounting Studies, 15(4), 725-751.

Jang, Ji. In., Lee, K. J., Seo, Y. M. \& Cheung, J. H. (2016). Economic consequences of IFRS adoption in Korea: A literature review. The Journal of Applied Business Research, 32(6), 1649-1662.

Jeong, S. W. \& Lim, T. K. (2005). The effect of earnings persistence on analysts` forecast error and accuracy. Korean Accounting Review, 30(2), 209-235.

Kang, M. J., Lee, M. G. \& Lee, H. Y. (2013). The impact of financial reporting comparability on analyst forecasts and value relevance. Korean Accounting Research, 38(1), 281-320.

Kim, Y. B. \& Kim, G. S. (2015). Short-term and long-term changes in the value relevance of the K-IFRS adoption. Korean Accounting Review, 40(4), 111-140.

Kim, Y. W., Choi, Y. S., Kim, J. H. \& Kim, H. W. (2014). Value relevance of consolidated versus separate financial statements under IFRS regime. Korean Accounting Review, 39(1), 117-146.

Lang, M. \& Lundholm. (1996). Corporate disclosure policy and analyst behavior. The Accounting Review, 71(3), 467-492.

Lee, K. J., Jin, J. J. \& Lee, B. H. (2015). Changes in the quality of accounting information with the adoption of IFRS in Korea. Pan-Pacific Journal of Business Research, 6(1), 35-45.

Leuz, C. \& Verrecchia, R. (2000). The Economic Consequences of increased Disclosure. Journal of Accounting Research 38 (supplement), 91-124.

Oh, H. M. \& Shin, H. Y. (2016). Voluntary disclosure, information asymmetry and corporate governance after the adoption of IFRS. Accounting Information Research, 34(2), 159-188.

Shin, H. Y., \& Park, H. J. (2014). The effect of financial statement comparability on divergence of opinion among investors. Korean Accounting Review, 39(2), 265-311.

Yip, W. Y. \& Young, D. (2012). Does mandatory IFRS adoption improve information comparability? The Accounting Review, $87(5), 1767-1789$.

Yoon, N. \& Mo, K. (2016). The effect of IFRS adoption on the optimism in analysts' stock recommendations: Evidence from Korea. Korean Accounting Review, 41(1), 83-112. 


\section{NOTES}

